\title{
COMPARATIVE STUDY OF REGIONAL DEVELOPMENT IN TEHRAN AND SISTAN AND BALUCHESTAN
}

\author{
Ali Asghar Pilehvar ${ }^{*}$, Amin Harasani $^{2}$ \\ ${ }^{1}$ University of Bojnord, $4^{k m}$ to Esfarayen road, Bojnord, 1339, Iran, pilevar@ub.ac.ir, 10098915385 \\ 9458) \\ ${ }^{2}$ Tehran University of Art, $4{ }^{k m}$ to Esfarayen road, Bojnord, 1339, Iran, amin.harasani.76@gmail.com
}

\begin{abstract}
The purpose of this article is to identify and analyze the extent of regional differences in terms of human development and economic development indices. In this study, the level of national-regional development in the two provinces of Tehran and Sistan and Baluchestan is measured by the above two indices to highlight discrepancies in regional development in Iran. In this applied research, a descriptive-analytical method has been adopted. The research data were obtained from the official Census of 2011 as well as the last official Census in 2016. The economic index was measured by Izard model and the conclusions were informed by the human development index. The results manifest that the studied indices have been affected by geographical factors and micro/macro policies of the government in the four decades since the 1979 Revolution, contributing to the widening of regional development gap. The HDI was 0.720 in Tehran and 0.494 in Sistan and Baluchestan. Also, the per capita income index of Tehran and Sistan and Baluchestan were 0.497 and 269.0, respectively, which indicates a marked difference. As for the average years of study, the index of Tehran (0.780) was nearly two-fold higher than that of Sistan and Baluchestan (0.439). However, the life expectancy index exhibited a smaller difference than the overall average. The results of the research based on the Izard model also demonstrate that Tehran and Sistan and Baluchestan with an average of $126 \%$ and $172 \%$ in economic sectors are above the national average (112\%), the only difference being that the development process in Sistan and Baluchestan is changing rapidly.
\end{abstract}

\section{Keywords}

Comparative study, regional development, Tehran, Sistan \& Baluchistan

\section{JEL Classification}

R58 Regional Development Planning and Policy

O15 Human Resources, Human Development, Income Distribution, Migration

DOI: https://doi.org/10.14311/bit.2021.01.03

Editorial information: journal Business \& IT, ISSN 2570-7434, CreativeCommons license (c) (i) published by CTU in Prague, 2021, http://bit.fsv.cvut.cz/ 


\section{Introduction}

In recent decades, along with changes in development pace of countries, scholars in economic, social, geographical, planning, etc. fields have dedicated growing attentions to national-regional development. The process of globalization, unbalanced distribution of income and economic opportunities, the type of national and regional micro and macro policies, and distinct approaches to decentralization or decentralization are some drivers of this research proliferation (Sabic \&Vujadinovic, 2017). In the process of national-regional development, it is important to recognize the level of regional development and differences. It is because in the regional development of each country, this process runs the risk of slowing down the entire economy. Therefore, identifying and measuring inequalities is of great importance in terms of formulating effective economic policies.

Moreover, the realization of this goal in the process of national development and planning is a function of recognizing the level of development in regions and their differences. The body of research in Iran shows that different regions and provinces, influenced by historical, cultural, geographical, nationalregional policies, and micro and macro factors, have taken different paths (Zarabi \& Izadi, 2013). Land reform in the 1960s, the industrialization strategy in the Fourth Development Plan (1971-1967), the establishment of industrial hubs in the vicinity of major cities, the 1979 Revolution, the Iran-Iraq war, etc. have triggered structural and functional changes in different regions and cities of Iran. The outcomes of these changes expose differences in economic development of provinces over the last years (Ziari et al., 2011). In Tehran (the capital) as a center for the concentration of population, capital and economic activities, centralism has been intensified over several decades. At the same time, Sistan and Baluchestan have been largely deprived of growth and development manifestations and the process of development has faced a plethora of obstacles such as absence of large industries, ruralurban migration, ethnic-religious issues, water shortage, etc. Therefore, inappropriate centralization strategy (population, activity and capital) in the provinces of Iran has intensified economic development in the regions and triggered discrepancies in development or backwardness.

After the 1979 Revolution, the government attempted to formulate policies in form of regional planning, with the goal of decentralizing metropolises (as the center of population and economic activities) and alleviating regional differences. It seeks to diminish, as pointed by Schumacher, the duality of economic growth and development in developing countries such as Iran. (Nasrollahi et al., 2011). This paper provides a concrete experience of regional development differences in a developing country. On the one hand, the new (Islamic) government has tampered with centralization and decentralization strategies in regional development in a trial and error fashion since 1980, and this experimentalism has intensified regional development discrepancies. On the other hand, international sanctions and rising economic inflation have slowed down the growth of the national economy. This has also contributed to stabilizing or aggravating regional development issues. This article aims to shed light on differences and the status of regional development in these two provinces through the comparison of official data derived from 2011 and 2016 national censuses.

To achieve this goal, we seek to answer the following two questions.

1. Do differences in the HDI of the two provinces under study prioritize the need for bottom-up planning and the implementation of effective strategies?

2. What are the effects of centralism or decentralization approach on regional development disparities between Tehran and Sistan and Baluchestan provinces? 


\section{Research background}

On an international scale, many studies have explored the relationship of investment and economic centralization with regional development or vice versa. Zhang (2007) argues that economic centralization, coupled with political centralization and support, aggravates regional inequality and differences (Zhang, 2007). Yu et al. (2011) also point to the positive relationship between foreign investment in one region and the intensification of discrepancies in other regions (Yu, et al, 2011). The results of Florida's (2011) study revealed that three factors of technology, potential and tolerance are involved in the development of each region. That is, in the presence of these three factors, a region can lay the ground for attracting creative labor and promoting emergence of innovation and technology, which in turn contribute to regional balance (Florida, 2011). Ali and Mingque (2018) reported that foreign and domestic investment in the long run has a significant and positive impact on the growth of developing Asian countries such as Pakistan, Thailand, and can mitigate regional development disparities (Ali \& Mingque, 2018). The findings of Feriyanto et al. (2019) revealed that the production rate of economic sectors and the real growth of GDP spikes as a result of domestic and foreign investment (Feriyanto et al, 2019). Extensive studies have investigated this subject on national and regional scales. Al-Emran and Al-Emran (2012) sought to measure the impact of human capital promotion on the economic growth of OPEC countries, concluding that the human factor (intellect and creativity) has a greater effect on rapid economic growth than physical infrastructure (Al-Emran \& AlEmran, 2012). Mahidol et al. (2016) studied the causal relationship between HDI and economic growth in Iran using a nonlinear model approach. They reporteda positive relationship between rising oil revenues, economic growth and improvement of human development index in different regions of Iran (Mahdilo et al., 2016). Sadeghi Shahedani and Khosravi (2016) also asserted that preparation and implementation of Iran's 5-year Development Plans in post-1979 Revolution era has affected Iran's national and regional economy in terms of income distribution and growth (Sadeghi Shahedani \& Khosravi, 2016). Eta'at and Dabiri (2016) studied the effects of centralism and immigration in Tehran. Their results underscored the approach to the strategy of centralism in Iran, suggesting that economic, demographic, cultural, political concentration in Tehran has given rise to industrial and demographic poles. According to their comparative study, the process of regional growth and development has mounted environmental threats and provoked regional inequality (Eta'ati, 2016). Feizabadi and Zahedi (2018) in another study on the analysis of socio-economic inequalities of development in rural areas of Iran argued that HDI places humans at the center of development models. By examining the development process between Tehran and Sistan and Baluchestan, they concluded that Tehran and Sistan and Baluchestan, as a migrant receiving and migrant sending communities, respectively, have influenced human development differences and subsequent regional development in these areas (Feizabadi \& Zahedi, 2018).

\section{Theoretical Foundations}

\section{Endogenous growth theory}

In the early 1990s, the ideas of Paul Romer and Robert Lucas introduced new concepts to the field of regional growth and development. They developed the concept of endogenous growth inspired by technology and innovation. The endogenous grow this a process that promotes human capital through skills, creativity and innovation, leading to the improved efficiency of labor and human development in a region. The main idea of this theory was put forth by Schumpeter (Mohammad zadeh et al., 2017). Therefore, in the literature on endogenous growth, human development is the key to economic growth and development and thus a top priority of governments (Bergman \& Feser, 2017). Human development puts humans at the heart of development models (Feyzabadi \& Zahedi, 2018). The HDI 
report released by the UNDP is a valid database with extensive applications in scientific analyses. According to this index, the development of different countries is measured based on data obtained from diverse aspects including life expectancy, general education and household income (Bakhshudeh, 2006). In this research, the UN database has been employed for the analysis of the HDI, as shown Table 1. Also, in Table 2, countries are classified in terms of human development index that Iran is in the top category of human development.

Table 1: Iran's ranking in human development indicators

\begin{tabular}{|c|c|}
\hline Classification of countries in HDI index & Amounts \\
\hline Very high & $1-0.800$ \\
\hline High & $0.800-0.700$ \\
\hline Medium & $0.700-0.550$ \\
\hline Low & $0.550-0$ \\
\hline
\end{tabular}

Source: UN, 2020

Table 2: Classification of countries based on HDI

\begin{tabular}{|c|c|c|c|c|c|c|}
\hline Rank & Country & $\begin{array}{c}\text { HDI } \\
\text { (value) }\end{array}$ & $\begin{array}{c}\text { Life } \\
\text { expectancy at } \\
\text { birth (years) } \\
\text { SDG3 }\end{array}$ & $\begin{array}{c}\text { Expected } \\
\text { years of } \\
\text { schooling } \\
\text { (years) } \\
\text { SDG 4.3 }\end{array}$ & $\begin{array}{c}\text { Mean years of } \\
\text { schooling } \\
\text { (years) SDG 4.6 }\end{array}$ & $\begin{array}{c}\text { Gross national } \\
\text { income (GNI) per } \\
\text { capita (PPP \$) } \\
\text { SDG 8.5 }\end{array}$ \\
\hline 61 & Malaysia & 0.804 & 27,227 & 10.2 & 13.5 & 76.0 \\
\hline 62 & Seychelles & 0.801 & 25,077 & 9.7 & 15.5 & 73.3 \\
\hline 63 & Serbia & 0.799 & 15,218 & 11.2 & 14.8 & 75.8 \\
\hline 63 & Trinidad & 0.799 & 28,497 & 11.0 & 13.0 & 73.4 \\
\hline 65 & Iran & 0.797 & 18,166 & 10.0 & 14.7 & 76.5 \\
\hline 66 & Mauritius & 0.796 & 22,724 & 9.4 & 15.0 & 74.9 \\
\hline
\end{tabular}

Source: UN, 2020

In the new theories, human capital is a perquisite for economic and regional growth and development (Zubair \& Motameni, 2020). Human capital originates from education, skills and creativity. Education and skills are key factors for economic growth that have a bearing on endogenous lifestyle and development (Hafner \& Mayer, 2013). It is also driven by the impact of education on improving the techniques and development of new ideas. (Hassan \& Rafez, 2017) Therefore, it can be argued that endogenous growth is an endogenous factor that feeds on social and human capital, leaving a direct effect on national-regional growth and development.

\section{Growth and imbalance theory}

As regards national-regional growth and development, diverse theories and strategies have been presented by economist and development literature. Each of these theories has adopted a distinct approach to this subject. The advocates of the classical theory contend that population concentration 
and its geographical distribution are main drivers of regional growth and development (Petrakos \& Saratis, 2000) However, neoclassical economists investigate the contribution of technology and capital to the economic growth of an important region (Rahmani \& Bagherpour, 2017). Still, the advocates of new theories in economic development like François Peru present the growth pole model as an effective strategy in regional development while others regard it as a vehicle for socio-economic change and alleviation of regional disparities (Bergman \& Feser, 2017). John Friedman also posits that the growth pole strategy is effective in regional development and mitigating inequalities. (Friedman, 2017) Michael Porter also maintains that competitiveness and competitive strategy in regional economy are associated with social progress and sustainable growth (Snowdon \& Stonehouse, 2006). Among the theories closely associated with the subject of this research, Gunnar Myrdal's theory of growth and imbalance takes precedence. He argues that the growth and development in a region can lead to the stagnation in other regions. This is particularly true in backward and developing countries. According to Myrdal, inequality and regional differences in these countries are on rise in the absence of economic integration, growth stimuli and deterrents of recession. Thus, economic integration is significantly linked to regional development, which contributes to national convergence (Antonescu, 2014). The theory of economic underdevelopment reflects another aspect of Myrdal's ideas that underline the impact of external factors such as investing on regional differences. This implies that developed regions are more successful in the race for investment attraction, which in turn intensifies regional differences (Aritenang, 2018). He also highlights the role of governments in stimulating growth factors such as capital, labor, etc. Myrdal's theories of growth and underdevelopment are directly linked to the subject of this article and can be considered as the basis of analysis.

\section{Methodology}

In this applied research, a descriptive-analytical method has been adopted. The statistical population consisted of Sistan and Baluchestan and Tehran provinces. Data was collected from official documents of 2011 and 2016 Censuses. In the analytical section, HDI and the Izard model were utilized.

1. HDI indicates real per capita income, life expectancy at birth and access to education at primary and secondary grades, which is calculated from formula 1 :

$$
\frac{\text { Most data }- \text { current status }}{\text { Highest data }- \text { lowest value }}
$$

The values of this index are in the range of $0-1$, where 0 indicates the lowest and worst condition and 1 denotes the highest and optimal condition.

2. Izard model is employed to analyze the economic situation in order to identify and predict the share of regional economic sectors compared to the national sector.

Izard's model analyzes and compares regional economic development discrepancies with the national development. In the model, four positions have been specified, which reflects the status of each economic sector in terms of growth and improvement in comparison with the overall average. Figure 1 presents the urban-regional economy (Figure 1). 


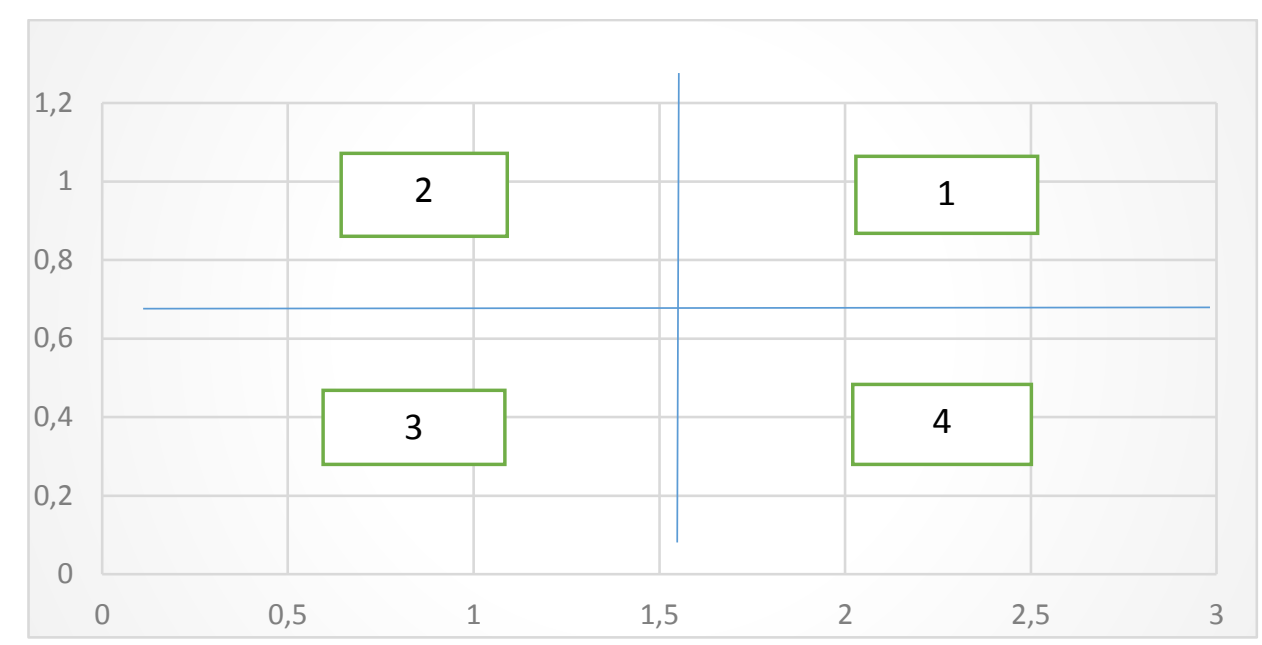

Figure 1. Izard's model in urban-regional economy

- If the sector in question is assigned to Section 1, its status will be above the average economic growth.

- If the sector in question is assigned to Section 2 , its status will be above the average growth rate.

- If the sector in question is assigned to Section 3, its status will be below the average growth on national and regional scales.

- If the sector in question is assigned to Section 4, its status will be above the national level and below average growth at the regional level.

Iran, one of the leading countries in Southwest Asia with a population of 80 million, has 31 provinces and shares border with 15 countries. Due to its geopolitical and geostrategic position, Iran is of geopolitical importance in the Middle East. The vast oil, gas and mineral reserves in Iran have provided vast opportunities for national regional growth and development over the decades. However, poor management and planning, reliance of oil revenues, international sanctions, etc. have hampered economic growth and development on the national-regional and local scales. As such, the analysis of hindrances and disparities in growth and development between northern and southern regions based on existing data suggests that northern regions of Iran have developed more rapidly than the southern regions, which have vast oil and gas reserve. It has something to do with natural conditions and greater concentration of population and activity.

The study area covers Tehran in the northern and Sistan and Baluchestan province in the south of Iran. Tehran and Sistan and Baluchestan were selected to give a clear picture of the level of regional growth and development differences. The study area is shown in Figure 2. 


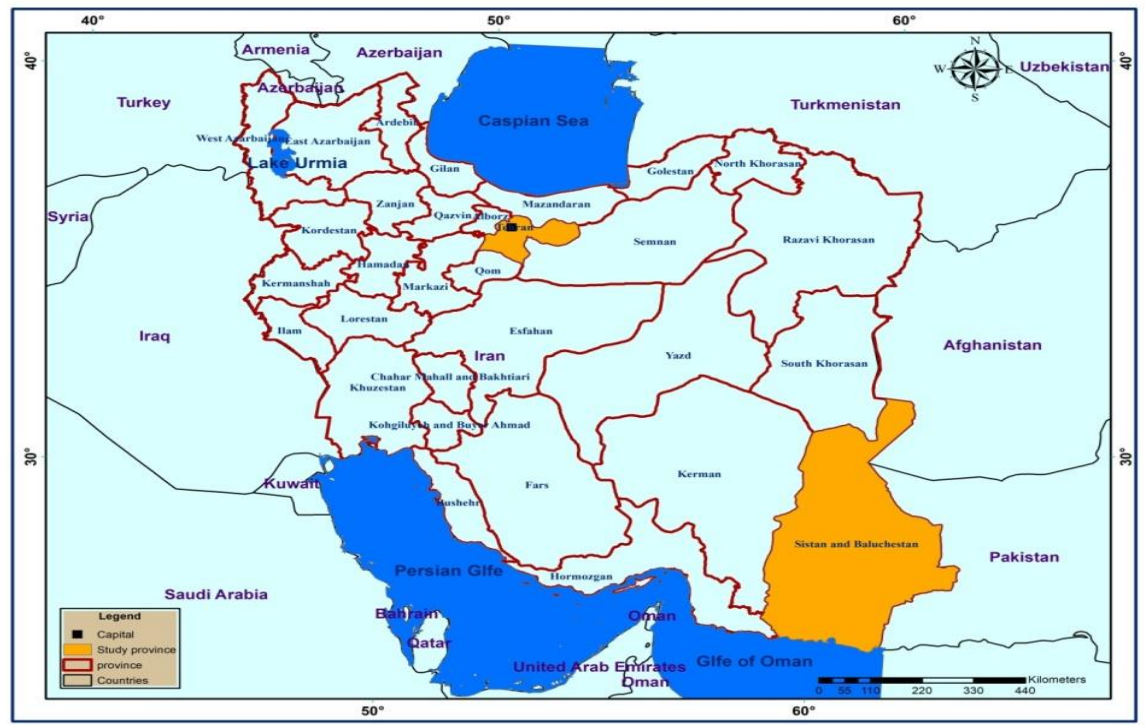

Figure 2: Iran' provinces and Geographical location of Tehran and Sistan \& Baluchestan

Source: Authors, 2021

The study of socio-economic status of the study area in the last Census (2016) reflects significant differences. The government's approach to centralism in metropolises like Tehran, lack of regional planning, environmental and geographical constraints in Sistan, concentration of capital and population in Tehran, migrant-receiving role of Tehran and migrant-sending role of Sistan and Baluchestan, rising inflation, lack of economic competition, among other things. Are some of factors closely associated with discrepancy in the process of regional growth and development? Unemployment rate shows that these two provinces are almost identical. Due to international sanctions, paucity of foreign and domestic investment, inflation, etc., the unemployment rate has been on rise in Iran, Table 2 shows social data and the scope of research.

Table 2: Socio-economic data of Tehran and Sistan \& Baluchestan

\begin{tabular}{|c|c|c|c|c|c|c|}
\hline $\begin{array}{c}\text { Indexes- } \\
\text { Rate }\end{array}$ & $\begin{array}{c}\text { Area } \\
\mathrm{km}\end{array}$ & $\begin{array}{c}\text { Percentage } \\
\text { of } \\
\text { population } \\
\text { of total }\end{array}$ & $\begin{array}{c}\text { Literacy } \\
\text { percent }\end{array}$ & $\begin{array}{c}\text { Unemployment } \\
\text { percent }\end{array}$ & $\begin{array}{c}\text { Economic } \\
\text { participation } \\
\text { percent }\end{array}$ & $\begin{array}{c}\text { Percent of } \\
\text { GDP (to the } \\
\text { national } \\
\text { average) }\end{array}$ \\
\hline Tehran & 12981 & 16.6 & 92.9 & 11.6 & 40.2 & 23.9 \\
\hline $\begin{array}{c}\text { Sistan \& } \\
\text { Bluchestan }\end{array}$ & 180726 & 3.37 & 72 & 11.5 & 29 & 1.3 \\
\hline
\end{tabular}

Source: Karimi Dastnaei, 2017 and Ramezanzadeh et al., 2016 


\section{Results}

\section{HDI Analysis}

HDI places a premium on per capita income, life expectancy, and access to education at primary and secondary grades. For the analysis of $\mathrm{HDI}$, first the data are presented in Table 3.

Table 3: HDI data in Iran, Tehran and Sistan \& Baluchestan

\begin{tabular}{|r|r|r|r|}
\hline Index & $\begin{array}{r}\text { Sistan \& } \\
\text { Baluchestan }\end{array}$ & Tehran & Iran \\
\hline $\begin{array}{r}\text { Life expectancy rate } \\
\text { (years) }\end{array}$ & 67.45 & 76.05 & 74 \\
\hline Literacy rate (percentage) & $\% 76$ & $\% 92.9$ & $\% 87.6$ \\
\hline Per capita income (\$) & 1407 & 4865 & 3714 \\
\hline
\end{tabular}

Source: Authors, 2021

In the next step, to determine HDI in the study are, the life expectancy, the average years of study instead of the literacy and per capita domestic income (using the formula of Maximum data - current status) / (highest value - lowest value) were calculated. The results are shown in Table 4. We defined the results in the range $0-1$, with 0 denoting the lowest and worst condition and 1 indicating the highest and optimal condition.

Table 4: HDI values in Tehran and Sistan \& Baluchestan

\begin{tabular}{|l|l|l|l|l|}
\hline & $\begin{array}{l}\text { HDI } \\
\text { adapted }\end{array}$ & $\begin{array}{l}\text { Domestic } \\
\text { per capita } \\
\text { income }\end{array}$ & $\begin{array}{l}\text { Average } \\
\text { academic } \\
\text { year }\end{array}$ & $\begin{array}{l}\text { Life } \\
\text { expectancy }\end{array}$ \\
\hline Tehran & 0.720 & 0.497 & 0.780 & 0.884 \\
\hline $\begin{array}{l}\text { Sistan \& } \\
\text { Baluchestan }\end{array}$ & 0.494 & 0.439 & 0.439 & 0.748 \\
\hline
\end{tabular}

Source: Authors, 2021

As shown in Table 4, HDI is 0.720 in Tehran and 0.494 in Sistan and Baluchestan. As regards GDP per capita index, a marked difference was found between Tehran (0.497) and Sistan and Baluchestan (0.296). As for the average years of study, Tehran (0.780) is almost two-fold higher than Sistan and Baluchestan (0.439). However, the life expectancy index exhibits a lower degree of disparity compared to the overall average. Therefore, according to the UNDP classification, Tehran and Sistan and Baluchestan provinces are classified as cities with high and low HDI, respectively.Tehran has a distinct position in the process of national-regional growth and development due to its geographical density and political-administrative function. Sistan and Baluchestan, on the other hand, struggles with competitive advantages due to poor socio-economic conditions (see Table 2), especially because regional development is a function of competitive advantage (Zeibote et al, 2019). Therefore, it is safe to claim that labor force is a regional advantage. When the human factor (a production factor) develops in an area, the economic situation is affected (Wolff, 2017). Conversely, a fall in HDI leads to unemployment and migration and aggravation of backwardness in the development process. There is ample evidence that improving the business environment and supporting the creative workforce in 
less developed areas can foster the development of that area (Bratik, 2014). Creative labor force, which is directly related to literacy and improvement of business environment, can contribute to entrepreneurship and establishment of innovation growth centers, reduce the regional issues in provinces the like of Sistan and Baluchestan, and upgrade growth and development indicators.

\section{Izard model analysis}

Using the data reported by the Statistical Center of Iran in 2011 and 2016 as well as Izard model, we explored changes in the economic status of Sistan and Baluchestan and compared it with national average, as presented in Table 5. Due to its hot and dry climate and infertile soil, agriculture is out of picture in this region. The government has also been sluggish in adopting an effective strategy for strengthening light and heavy industries in this region and the growth of industrial sector has been thwarted. This approach has deteriorated smuggling and large-scale migration. According to Table 5, the highest changes appeared in the service sector (223\%).

Table 5: The changes in the economic sectors of Sistan \& Baluchestan in the Izard model

\begin{tabular}{|c|c|c|c|c|c|c|}
\hline & \multicolumn{3}{|c|}{ Iran } & \multicolumn{3}{c|}{ Sistan \& Baluchestan } \\
\hline \multirow{2}{*}{ Indexes } & Change & Employees & Employees & Change & Employees & Employees \\
(percent) & 2011 & 2016 & 2011 & 2016 \\
\hline Agriculture & 105.9 & 3766862 & 3989537 & 133.7 & 103445 & 138378 \\
\hline Industry & 108.2 & 6837675 & 7402553 & 138 & 153640 & 212080 \\
\hline Services & 118.2 & 9867542 & 11668821 & 223 & 179392 & 401599 \\
\hline Total & 112.6 & 20472079 & 23060911 & 172.3 & 436477 & 752057 \\
\hline
\end{tabular}

Figure 3 also depicts the extent of change in the three economic sectors of Sistan and Baluchestan within the framework of Izard's model.

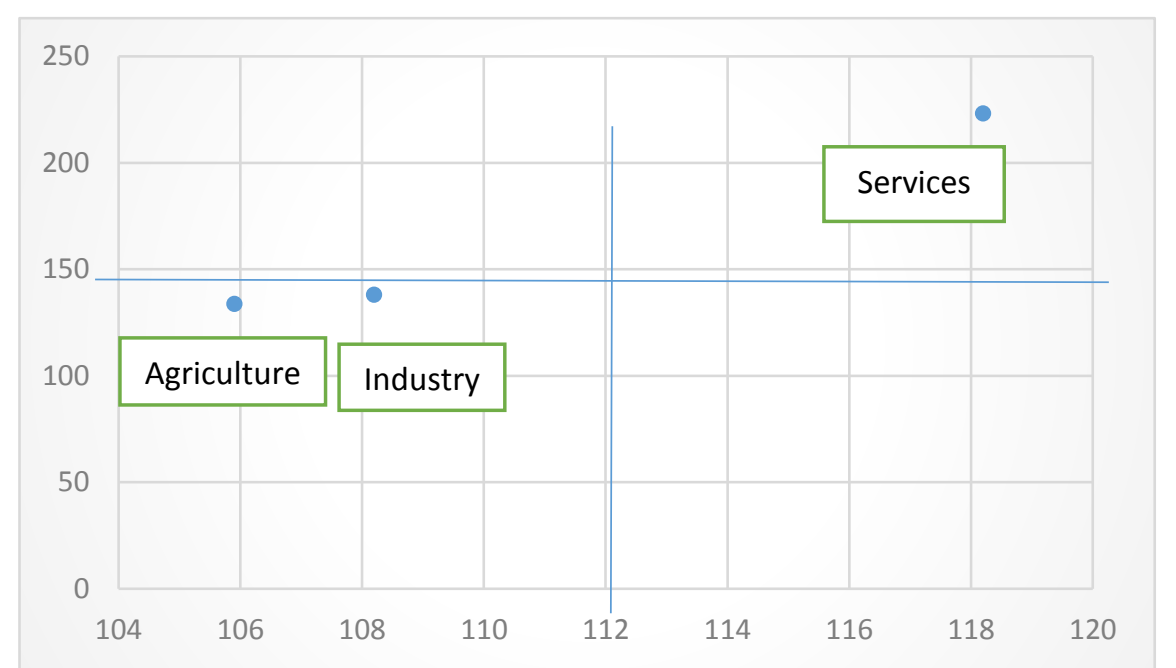

Figure 3. The changes of the three economic sectors of Sistan \& Baluchestan in Izard model Source: Authors, 2021

As the data in Table 5 and Figure 3 show, the service sector is drastically different from other economic sectors. In the industry and agriculture sector, however, the performance of this province is below 
national and regional average growth. Therefore, according to Table 5 and Figure 3, the agricultural, industrial and service sectors of Sistan and Baluchestan province have witnessed a higher growth than the whole country. This trend reflects the government's decentralization approach and development measures to diminish the regional development gap in Sistan and Baluchestan province. Despite a surfeit of problems induced by international sanctions, inflation, etc., the industrial and agricultural sectors have also contributed to the economic growth and regional development of Sistan and Baluchestan, thus paving the way for balancing the process of national-regional growth and development. Data taken from the Statistical Center of Iran manifest changes in the three economic sectors of Tehran, which are compared with the national average in Table 6. According to the table, the change in the service sector has surpassed that of agriculture and industry sectors. Changes at the national level also transcend the service sector. The reason can be sought in the lack of attention to effective policies and strategies in the agricultural sector and the inefficiency of Iran's industrialization strategy over several decades. The growth of urbanization (74\%) in Iran has also been associated with the rising share of the service sector in all areas (131\%), which indicates a marked difference in relation to other sectors.

Table 6: The changes in the economic sectors of Tehran in the Izard model

\begin{tabular}{|c|c|c|c|c|c|c|}
\hline & \multicolumn{3}{|c|}{ Iran } & \multicolumn{3}{|c|}{ Tehran } \\
\hline Indexes & $\begin{array}{l}\text { Change } \\
\text { (percent) }\end{array}$ & $\begin{array}{c}\text { Employees } \\
2011\end{array}$ & $\begin{array}{c}\text { Employees } \\
2016\end{array}$ & $\begin{array}{l}\text { Change } \\
\text { (percent) }\end{array}$ & $\begin{array}{c}\text { Employees } \\
2011\end{array}$ & \begin{tabular}{|c|} 
Employees \\
2016
\end{tabular} \\
\hline Agriculture & 105.9 & 3766862 & 3989537 & 117 & 43343 & 50723 \\
\hline Industry & 108.2 & 6837675 & 7402553 & 117 & 1111448 & 1307104 \\
\hline Services & 118.2 & 9867542 & 11668821 & 131 & 1941165 & 2547878 \\
\hline Total & 112.6 & 20472079 & 23060911 & 126 & 3095956 & 3901805 \\
\hline
\end{tabular}

Source: Statistics Center of Iran, 2019

As displayed in Figure 4, the growth of service sector in Tehran has surpassed that of national growth.

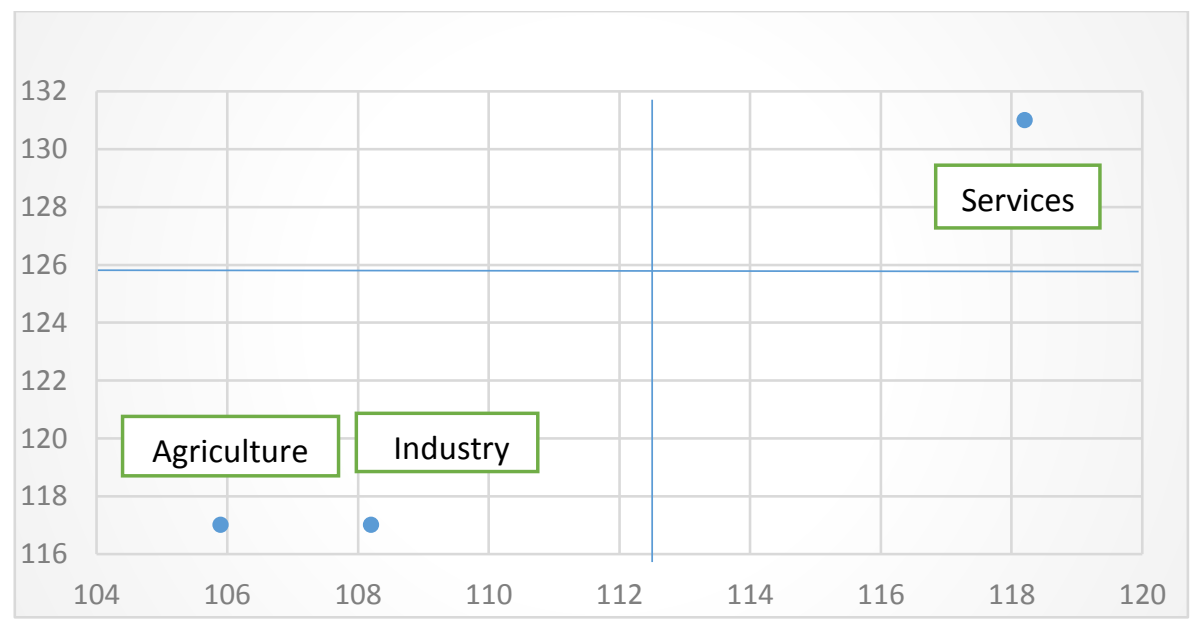

Figure 4: The changes of the three economic sectors of Tehran in Izard model

Source: Authors, 2021

The deployment of international organizations and companies coupled with the politicaladministrative function of Tehran can explain this situation. Tehran's agricultural and industrial sectors 
are also in a better position than national and regional growth. The growth, driven by population density and solid infrastructure, is induced by political-administrative conditions, as well as the geographical concentration of industries and the economies of scale. In general, Tehran's agricultural sector growth has transcended national growth; through it still makes up a low share of Tehran's economy. Comparative-analytical findings of the Izard's model in the provinces studied based on Tables 5 and 6 as well as Figures 3 and 4 reveal the trend of change and economic growth with a focus on the service sector compared to the national level. Nonetheless, the service sector in Sistan and Baluchestan reflects enormous change (223\%) in comparison with the Tehran and the entire country. This trend is compelled by rural-urban migration and the government's disregard for the agriculture and industrial investment. It seems that the policy of decentralization in Tehran and the pursuit of regional development plans aimed at national-regional balance have turned the spotlight on the problems of regions such as Sistan and Baluchestan. Despite the apparent growth, the development has failed to keep pace, which warrants further attention in regional planning for development. A comparison of the economic situation of these two regions reflects that centralization (in Tehran) and decentralization (in Sistan and Baluchestan) has been concurrent in the process of regional development, which has led to the escalation of differences.

\section{Discussion}

The HDI index in Tehran and Sistan and Baluchestan provinces are 0.492 were 0.720 , respectively. Comparison of these values with the classified data reported in the UNDP shows that Tehran is in the high human development category and Sistan and Baluchestan falls in the low human development category (two levels below Tehran). Therefore, in light of the abating trend of activity-population concentration in Iran, services, education, health and life expectancy and people are still more concentrated in Tehran. This level of concentration is beyond the economic growth of the regions and meets the goals of sustainable local-regional development. The economic status of the two provinces studied in the Izard's model reveals that the situation of service sectors in Tehran and Sistan and Baluchestan provinces is more promising than the national average. In Tehran, the concentration of various national and international companies and its administrative-political function, and in Sistan and Baluchestan, the debilitated industry and agriculture sector has augmented the share of the service sector. In agriculture and industry, however, both are below the national average. Imbalanced growth and development of the three economic sectors in the face of international sanctions, lack of investment and inflation, weak competitiveness and underlying economic stimuli expose regional discrepancies in economic sectors. The geographical and topographical conditions of Iran and inefficient policies in the agricultural sector as well as diminished share of this sector in the economy can adversely affect the self-sufficiency of agricultural products and mount a threat to the food security of Iran. Due to the policies and planning of the industrial sector, especially the oil and gas industry, the developing trend of this sector, as a stimulus for the regional economy in southwestern Iran, has been noticeable. Nevertheless, Sistan and Baluchestan in the southeast of Iran have been bereft of the industrialization strategy. If this trend is sustained, migration from Sistan and Baluchestan province will be boosted, which can wreak havoc on huge human and social capita. As a consequence, endogenous development will be halted and competitive advantages taper off, which consequently undermines human development and regional growth. Meanwhile, Tehran continues to capitalize on centralism, with its human development being strengthened due to its national-regional function. 


\section{Conclusion}

The national and regional planning in Iran dates back to the 1950s. The approach to 5-year development plans to lessen regional differences and exploit natural and human capacities of different regions of Iran has been one of the goals of this planning. 70 years of planning experience has come at the cost of unbalanced growth and development in the regions so that in some provinces, quantitative and qualitative indicators demonstrate a marked difference while these programs were initially drafted and implemented to bolster regional balance and equilibrium. At first glance, comparison of Tehran with other regions of Iran is misleading, because Tehran, as the capital, has access to government support and powerful infrastructures. Even though this study manifested similar outcomes between Tehran and Sistan and Baluchestan provinces, the government has been pursuing balanced growth and development in different regions of Iran for several decades by planning and implementing economic projects and decentralization. The outputs of these programs have been nothing but widening regional gaps and backwardness of provinces such as Sistan and Baluchestan in various dimensions of development. It is while the vast potentials and capacities of this province and the region can be main competitive advantages or drivers of development. In order to promote the level of growth and development in Iran in general and Sistan and Baluchestan in particular, two important points should be heeded and incorporated at the national, regional and local policies:

First, from a physical and infrastructural perspective, special attention should be allocated to the accumulation of capital in provinces such as Sistan and Baluchestan to provide an economic stimulus in the growth and development process.

Second, cultural and human dimension should be stressed as the basis of national-regional development. It can strengthen endogenous growth through human development and this process can contribute to the sustainability of growth and national-regional development. Undoubtedly, changes in policy-making and consideration of these dimensions can trigger change and consequently create opportunities and competitiveness in the process of sustainable economic and social growth.

\section{Abbreviations}

HDI: Human development index

GDP: Gross district product

OPEC: Organization of the Petroleum Exporting Countries

UNDP: United Nations Development Program

SDG: Sustainable Development Goals

GNI: Gross national income

\section{Acknowledgements}

Special thanks to Dr. Vahid Mardani for undertaking the English grammar revision of the paper. 


\section{References}

[1] Al-emran, R., \& Al-emran, A. (2012). Measuring the Effect of Human Capital Promotion on Economic Growth in OPEC Selected Countries, Quarterly Journal of Parks and Growth Centers, 8(32), 41-53.

[2] Antonescu, D. (2014). Regional Development Policy in Context of Europe 2020 Strategy, Procedia Economics and Finance ,15.1091-1097. https://doi.org/10.1016/S2212-5671(14)00561-9

[3] Aritenang, Adiwan\& Son, JW. (2018). The effect of decentralization and free trade agreements on regional disparity in a developing economy: the case of Indonesia, 1993-2005. International Journal of Urban Sciences. https://www.researchgate.net/publication/334559193

[4] Bakhshode, M. (2006). Process of human development in Iran. Development and efficacy Journal ,1(2),1-8.

[5] Bartik, T. J. (2014). From Preschool to Prosperity: The Economic Payoff to Early Childhood Education. Kalamazoo, MI: W.E. Upjohn Institute for Employment Research. https://resear ch.upjohn.org/cgi/viewcontent.cgi?article=1246\&context=up_press

[6] Bergman, E. M., \&Feser, E. (2017). Regional Economic Development, DOI: 10.13140/RG.2.2.26251.95529,.1-18.

[7] Etaat,J, \& Dabiri.,A.A.(2017).Secretary: Evaluating the effects of centralism and immigration On increasing the ecological footprint of Tehran urban area. Geographical Research Quarterly, 31(3),56-66.

[8] Feriyantoa, N., M., \&Aiyubbic, D. E. (2019). Regional spillover effect to Gross Regional Development Product (GRDP) in The Special Region of Yogyakarta, Indonesia, Entrepreneurship and Sustainability,6(3), 1318-1334.

[9] Feyzabadi, Y., \&Zahedi, S. (2019). Analysis of Socio-Economic Inequalities of Development in Rural Areas of Iran. Quarterly Journal of Space Economics and Rural Development, 7(24), 19- 40.

[10] Florida, R. (2011). The Great Reset: How the Post-Crash Economy Will Change the Way We Live and Work. Harper Business, 240.

[11] Friedmann, J. (2017). Planning as a vocation: The journey so far,' in B. Haselberger, Encounters in Planning Thought: 16 Autobiographical Essays from Key Thinkers in Spatial Planning, 15-34. New York and London. Routledge.

[12] Hafner, A. \& Mayer, D. (2013). Fertility, economic growth and human development casual determinates of the developed lifestyle. Journal of macroeconomics ,38(3) 107-120. DOI: 10.1016/j.jmacro.2013.04.001

[13] Hassan, S., \& Rafez, N. (2017). The role of female education in economic growth of Pakistan A time series analysis from 1990-2016. international journal of innovation and economic development ,3(5), 83-93.DOI: 10.18775/ijied.1849-7551-7020.2015.35.2007

[14] Karimi Dastnaei, T. (2017). Tehran's economy indexes, Tehran chamber of Commerce, Industries, Mines and Agriculture. Economy research department, Tehran.

[15] Mahdilo, A., Asgharpor, H., \&Karimi, Z. (2017). Investigating the causal relationships between Human development index and economic growth in Iran with the non-linear model approach of MS-VAR.Quarterly Journal of Planning and Budget ,21(2), 25-53.

[16] MohammadzadehAsl, N., Seifi Pour, R., \&Mehrabian, A. (2017) The Impact of the Return of Research and Development on Economic Growth (Using Regression Quintiles Model), $8(15), 1-14$.

[17] Najafi, A., \& Mingque, Y. (2018). An Application of Vector Error Correction Model Approach In explaining the Impact of Foreign Direct Investment on Economic Growth of Asian Developing Countries. International Journal of Economics and Financial, 8(4), 133-139.

[18] Nasrollahi, Z., Ansari Samani, H., \&Rouzbahani, M. (2018). Estimate the Impact of Income Inequality on Sustainable Development Indicator: Study of Iran. Quarterly Journal of 
Economic Growth and Development Research, 8(32), 61-78.

[19] Petrakos, G., \& Saratsis, Y. (2000). Regional inequalities in Greece, Papers Reg. Sci, 79, 5774.DOI: 10.1111/j.1435-5597.2000.tb00759.x

[20] Rahmani, T., \&BagherpurOskoei, E. (2017). Examination of the Relationship between Economic Growth and Saving Rate in Low and High Inflation Countries. Quarterly Journal of Economic Growth and Development Research, 7(28), pp. 71-82.

[21] Ramazanzadeh, M., Ramazani, M., \& Ghasemi, R. (2017). Strategic Problemology of Development in Sistan and Baluchestan Province, The center for strategic studies, Tehran.

[22] Sabic, D.\&Vujadinovic, S. (2017). Regional development and regional policy, Collection of Papers - Faculty of Geography at the University of Belgrade, 65(1a), pp. 463-477.

[23] SadeghiShahedani, M., \&Khosravi, M. (2017). A Study of the Communities and Differences of Theoretical Foundations of Development Plans in the Islamic Republic of Iran, Quarterly Journal of Economic Growth and Development Research, 6(23), 14-32.

[24] Snowdon, B., \&Stonehouse, G. (2006). Competitiveness in a globalized world: Michael Porter on the microeconomic foundations of the competitiveness of nations, regions, and firms, Journal of International Business Studies, 37(2), 163-175.

DOI: 10.1057/palgrave.jibs.8400190

[25] Statistical center of Iran. (2019). A glance at the general population and housing census throughout the Tehran and sistan \& Baluchestan province, Tehran.

https://www.amar.org.ir/english

[26] UN. (2020). Human development report office, Latest Human Development Index (HDI) Ranking. Http://hdr.undp.org. Accessed 20 February 2021.

[27] Wolff, M. (2017). Understanding the role of centralization processes for cities - evidence from a spatial perspective of urban Europe 1990 - 2010. Cities, 75, 20-29.

[28] Yu, K., Xian, X., Ping, G., \& Xiaoyun, L. (2011) Foreign direct investment and China's regional income inequality, Economic Modelling ,28, pp. 1348-1353.

http://www.sciencedirect.com/science/article/pii/S0264-9993(11)00044-7

[29] Zarabi, A., \&Ezadi, M. (2013). Analysis of Iranian provinces development. Journal of spatial planning,3(1),101-116.

[30] Zeibote, Z., Volkova, T., \&Todorov, K. (2019). The impact of globalization on regional development and competitiveness: cases of selected regions, Insights into Regional Development ,1(1), pp. 33-47.

[31] Ziari, K., Sorkh kamal, K., Zanjirchi, M. \&Kami, M. (2010). Analytical Attitude on Growth Pole in Regional Development: A Case Study of Khorasan Razavi Province. Quarterly Journal of Environmental Planning, 5(17), 1-24.

[32] Zhang, J. (2007). China's economic growth: trajectories and evolving institutions, WIDER Conference Paper, United Nations University, Finland. DOI: 10.1093/acprof:oso/9780199580606.003.0004

[33] Zobeiri, H. \&Motameni, M. (2020). Human Capital and Economic Complexity in Iran. QJER, 20 (3), pp. 145-166. 